\title{
Vietnamese Constitutionalism: The Reform Possibilities
}

\author{
Pip NICHOLSON*
}

University of Melbourne, Australia

p.nicholson@unimelb.edu.au

The central question taken up by these pioneering papers is: "What does the 2013 constitutional debate and the subsequent constitutional reform signal in terms of political and legal reform in Vietnam?" More particularly, the papers analyze the actors, their debates, and the possible impacts of the constitutional consultation for Vietnamese constitutional reform across a range of issues including land, human rights, the role of the procuracy, political liberalization, and economic change. Ultimately these analyses inform us about the Communist Party of Vietnam (CPV)'s vision and pragmatism regarding its political and constitutional retention of power and the reform dynamics created by other state and non-state actors.

In this paper, I briefly explore recent China-related commentary on constitutional dialogue, particularly to elicit whether this can be used to explain the Vietnamese constitutional debates and their aftermath. I then turn to recent work on political protest in Vietnam to elicit whether its analysis sheds light on the performance of contemporary Vietnamese constitutional debates as presented in the accompanying papers.

I suggest that Vietnamese constitutional dialogue and its aftermath diverges from the Chinese experience in several fundamental ways. Firstly, Vietnam has officially allowed gradually escalating and now greater constitutional debate than its northern neighbour. Secondly, the Vietnamese party-state arguably lost, or at least partially lost, control of the constitutional debate in 20I2-20I3, which could have far-reaching consequences for the political and legal construction of the party-state over time. ${ }^{\mathrm{I}}$ Thirdly, the treatment of actors engaged in constitutional dialogue, as portrayed in these papers, evidences some common features with Kerkvliet's characterization of party-state treatment of Vietnamese dissident activity, in turn, characterized as different from that of China. In consequence, I suggest the Vietnamese and Chinese socialist experience of constitutional dynamics diverge, which in turn, at least leaves open the possibility of different reform trajectories, albeit ones that are not known. Accepting an argument that the Vietnamese party-state is more permissive of

* Professor of Law, Melbourne Law School; Director of the Asian Law Centre, Melbourne Law School.

I. BUI Ngoc Son and Pip NICHOLSON, “Activism and Popular Constitutionalism in Contemporary Vietnam" Law and Social Enquiry [forthcoming]. 
constitutional reform activism than China, and accepting that reform debates spawn new possibilities (see below), the reform dynamics in Vietnam may have more impact and may realize change in advance of their northern neighbour, albeit that the reform may not resemble Western, liberal constitutionalism.

Others have also pointed out the greater openness of Vietnam to constitutional dialogue than China. Fu and Bui analyze three "pillars" of socialist Vietnamese and Chinese constitutionalism comparatively: the leadership role of the Party, the role and relevance of socialist rule of law, and how each state adapts "to populism". ${ }^{2}$ The authors argue that Vietnam is more open to new constitutional norms than its Chinese counterpart as a result of having greater openness in key political structures (such as the competition to be elected to Central Committee positions and "more diffuse executive authorities"). ${ }^{3}$ Further the authors contend that Vietnam is more "open" to the influence of international law and more tolerant of "civil society" than China. ${ }^{4}$ Bui Ngoc Son identifies a contrast in the approach to constitutionalism between China and Vietnam. The Chinese approach, he argues, is to construct Chinese constitutionalism as an "exception" to that of Western liberal states. ${ }^{5}$ In contrast, Vietnam's constitutional debates are not premised on Vietnamese constitutional exceptionalism, but characterized as reflecting an "instrumentalist approach to global constitutionalism to enhance domestic legitimacy". "This analysis, while brief, focuses on contrasts between China and Vietnam in constitutional dialogue and reinforces these findings, at least in part.

Scale is also relevant here. As a small and relatively unified country of 94 million people, ${ }^{7}$ Vietnam is in marked contrast with China's population of nearly I.4 billion, ${ }^{8}$ stretched across a large land mass. The relative homogeneity of Vietnam (not forgetting there are 56 ethnic minorities) enables, as we shall see, a national conversation about constitutionalism, even if largely run by elites. This brief paper, however, has a limited focus and that is how these papers contribute to our understanding of Vietnamese constitutional dialogue and its relative openness. In consequence, I will not offer comment beyond the real possibility of constitutional conversation in Vietnam that includes those beyond and within the party-state, that is perhaps less open in China.

By way of background, in 2013 Vietnam passed its fifth constitution. The northern Democratic Republic of Vietnam, and its successor the Socialist Republic of Vietnam

2. FU Hualing and Jason BUI, “Diverging Trends in the Socialist Constitutionalism of the People's Republic of China and Socialist Republic of Vietnam" (Paper delivered at the "What is Socialist about Socialist Law? Exploring Epistemic and Institutional Change in Socialist Asia' Conference, University of Hong Kong,

28-29 October 2015) [unpublished paper] at 5.

3. Ibid at 7 .

4. Ibid.

5. BUI Ngoc Son, "Social Mobilisation and Comparative Constitutional Theory" [unpublished paper] at $82-85$.

6. Ibid at 85 .

7. "GeoHive-Current World Population” GeoHive (27 July 2016), online: GeoHive <http://www.geohive. com/earth/population_now.aspx $>$.

8. Ibid. 
from I975, have previously passed four constitutions. These can be characterized as: an independence constitution in I946; a socialist constitution in I959; a unification constitution in 1986; and a reformist doi-moi (renovation) constitution in 1992. ${ }^{9}$ This latter constitution was amended in $200 \mathrm{I}$. The introduction of the $20 \mathrm{I} 3$ constitution was preceded by the most open call for comment about the constitution yet witnessed in contemporary Vietnam, ${ }^{\text {IO }}$ provoking many submissions ${ }^{\mathrm{II}}$ including a petition from 72 intellectuals for wide-ranging and fundamental reform (commonly referred to as Petition 72$).{ }^{\mathrm{I} 2}$ Other groups also coalesced to promote change. ${ }^{\mathrm{I} 3}$

In this context, the significance of these papers needs to be explained. These papers offer the first detailed Vietnamese-authored English-language analyses of the 2OI2-20I3 constitutional reform actors, and their strategies, across a spectrum of constitutional issues, which have been brought together to enable rich comparison of debates in different spaces. Prior to this project there had been limited English language commentary, ${ }^{\mathrm{I}}$ with the exception of Bui Ngoc Son (and recently with Nicholson) and Mark Sidel. ${ }^{15}$ Bui Ngoc Son has written richly about constitutional dynamics in Vietnam both historically ${ }^{16}$ and in the

9. See generally Pip NICHOLSON, "Vietnamese Legal Institutions in Comparative Perspective: Contemporary Constitutions and Courts Considered" in Kanishka JAYASURIYA, ed, Law, Capitalism and Power in Asia: The Rule of Law and Legal Institutions (London and New York: Routledge, I999) 257 at 257-82; VU Dinh Hoe, "Les Quatres Constitutions du Vietnam" (I995) 24(2) Vietnamese Law Journal 24; and PHAM Van Bach and VU Dinh Hoe, "The Three Successive Constitutions of Vietnam" (1984) I International Review of Contemporary Law I05.

Iо. Bui and Nicholson, supra note I at 27.

II. See VO Tri Hao, "Integrating the Principle of Separation of Power into the Constitution Amendment 2013 within the "Keeping Face" Cultural Context" (Paper presented at "Constitutional Debate in Vietnam' Conference, National University of Singapore, I9-20 March 2016) [unpublished paper]. Vo reports that the National Assembly argued that 26 million people commented on the constitutional proposals (at I 2 ). Others point out that this 26 million counts every name as a single submission, counting singly those on group submissions.

I2. BUI Ngoc Son, "Petition 72: The Struggle for Constitutional Reforms in Vietnam" I-CONnect: Blog of the International Journal of Constitutional Law and ConstitutionMaking.org (28 March 2013), online: I-CONnect <http:/www.iconnectblog.com/2013/o3/petition-72-the-struggle-for-constitutional-reformsin-vietnam/>.

I3. See for example, Vo, supra note II at I3-I7. Vo groups the activists in 4 ways: reformist politicians; intelligentsia; dissidents; and blue capitalists. Along with those behind Petition 72 he outlines the work of the fragmented, but resilient, intelligentsia for its multifaceted approach to advocacy.

I4. BÙI Hải Thiêm, "Pluralism Unleashed: The Politics of Reforming the Vietnamese Constitution" (2OI4) 9(4) Journal of Vietnamese Studies I; Thiem H BUI, "Deconstructing the 'Socialist' Rule of Law in Vietnam: Changing the Discourse on Human Rights in Vietnam's Constitutional Reform Process" (20I4) 36(I) Contemporary Southeast Asia 77; HA Thi Mai Hien, "The Fundamentals of the Amended Constitution of 2013 on the Accountability of Constitutional Bodies and Implementation Outlook" (2015) I Vietnam Social Sciences 34; NGUYEN Thi Huong, "Pursuing Constitutional Dialogue within Socialist Vietnam: The 20I0 Debate" (20I2) I3(I) Australian Journal of Asian Law I.

I5. Mark SIDEL, “Analytical Models for Understanding Constitutions and Constitutional Dialogues in Socialist Transitional States: Re-Interpreting Constitutional Dialogues in Vietnam" (2002) 6(I) Singapore Journal of International and Comparative Law 42 [Sidel, "Analytical Models"]. See also Mark SIDEL, The Constitution of Vietnam: A Contextual Analysis (Oxford and Portland, Oregon: Hart Publishing, 2009) [Sidel, Constitution of Vietnam].

I6. See BUI Ngoc Son, Confucian Constitutionalism in East Asia (Abingdon, Oxon and New York: Routledge, 20I6) [Bui, Confucian Constitutionalism]; BUI Ngoc Son, "Restoration Constitutionalism and Socialist Asia" (20I 5 ) 37 Loyola of Los Angeles International and Comparative Law Review 67; BUI Ngoc Son, "Confucian Constitutionalism in Imperial Vietnam" (2013) 8 National Taiwan University Law Review 373; BUI Ngoc Son, “Confucian Constitutionalism: Classical Foundations” (20I2) 37 Australian Journal of Legal Philosophy 6I; BUI Ngoc Son, "The Introduction of Modern 
contemporary period. ${ }^{17}$ Most recently, Bui and Nicholson argue that popular constitutionalism exists in Vietnam, if that is understood as people-based activism (albeit largely elite) and not conceived as emanating from the judiciary as in the United States. ${ }^{\text {I8 }}$ Sidel's 200 I analysis of constitutional dialogue concluded that the party-state was more open than in earlier periods to a broader discussion and that, in turn, this might provoke further sites for change debates. ${ }^{19}$ Sidel's cautious optimism was arguably greatly exceeded by the debates of 201 2-2013.

The particular feature of these papers, however, is the range of constitutional debates covered, emanating from the same 20I2-20I3 period, and how this affords insight into a broader community of constitutional actors. The project was not to place constitutional reforms under the microscope, but to analyze the dialogue that preceded the moment of change/no change. The experience of the Vietnamese 2013 constitution-making exercise offered new and substantial debates, which the ensuing papers mined, many also comparing the 20I2-20I3 dynamics with those of 200I. The papers analyze the following: the resilience of Vietnamese single party leadership (Bui Hai Thiem); procuracy reforms (Pham Lan Phuong); contesting constitutional provisions on land ownership (Le Toan); the place of human rights in the constitution (Vo Cong Giao and Tran Kien); and constitutional reforms targeting the economy (Pham Duy Nghia). They offer insights into the political "signals" and strategies of the $20 \mathrm{I} 3$ constitutional dialogue while also offering the first counter-narrative to that of the National Assembly, although its official "story" is still being assembled. ${ }^{20}$ There may also be a dialogical impact generated by these interpretations.

In consequence, and as noted at the outset, this project affords a study of the transplantation of constitutional ideas: largely, as we will see, from the West to Vietnam. It is, however, a mistake to appropriate the rhetoric of law and development (rule of law will travel or, as here, constitutional principles will travel) given the evidence that transplants are rejected or adapted (even as between socialist states) ${ }^{2 I}$

Constitutionalism in East Asian Confucian Context: The Case of Vietnam in the Early Twentieth Century" (2012) 7 National Taiwan University Law Review 423.

17. See BUI Ngoc Son, "The Discourse of Constitutional Review in Vietnam" (2014) 9 Journal of Comparative Law I9I; BUI Ngoc Son, "Constitutional Developments in Vietnam in the First Decade of the Twenty-First Century" in Albert H Y CHEN, ed, Constitutionalism in Asia in the Early Twenty-First Century (Cambridge: Cambridge University Press, 20I4) 194; BUI Ngoc Son, "Central-Local Relations and the Constitutional Discourse on Political Decentralisation in 2Ist-Century Vietnam" in Andrew HARDING and Mark SIDEL, eds, Central-Local Relations in Asian Constitutional Systems (Oxford: Hart Publishing, 2OI 5) 57. See also BUI Ngoc Son, "Social Mobilization and Comparative Constitutional Theory" [forthcoming] and BUI Ngoc Son, "Constitutional Identity Change in the Contemporary Socialist World" [forthcoming].

I 8. Bui and Nicholson, supra note I at I 5-I 6, 50-60. However, we note the critique of this characterization of popular constitutionalism existing in the USA.

I9. For an analysis of the 200 I Vietnamese constitutional dialogue, see: Sidel, "Analytical Models" supra note I 5 . See also Mark SIDEL, Law and Society in Vietnam (New York: Cambridge University Press, 2008) at I-49.

20. The Chairman of the NA has commissioned an authoritative history of Vietnamese constitutional arrangements and their adaptation. While commissioned, this work has not been published at the time of this publication.

2I. Penelope (Pip) NICHOLSON, Borrowing Court Systems: The Experience of Socialist Vietnam (Leiden and Boston: Martinus Nijhoff Publishers, 2007) at 222-230. 
and have unintended consequences, even where there is the will to copy. ${ }^{22}$ And there is no evidence of the will to ape a liberal constitutional order in the collective Vietnamese leadership at this time. ${ }^{23}$ Let us turn to see what is to be learnt from analyses of Chinese constitutional dialogue.

\section{CHINESE CONSTITUTIONAL DIALOGUE}

China-focused constitutional scholarship written by outsiders seeks to explain how and why an authoritarian state allows constitutional debate and what the consequences of that permission might be. Hand argues that Chinese constitutional dialogue is part of a "grand mediation" orchestrated by the party-state. ${ }^{24}$ Further, Hand suggests that in order to fully appreciate the scale of this party-state mediation, it is necessary to consider how individual claims challenge the party-state alongside claims made by broadly constituted groups for constitutional change. ${ }^{25}$ In short, Hand seeks out "patterns of bargaining, consulting and mediating across a range of both intrastate and citizen-state constitutional disputes". ${ }^{26}$ Hand depicts a highly orchestrated party-state that has effective control over the development of the political-legal structures.

Yet this does not mean that the PRC has not struggled with protest. Sarah Biddulph details various policy areas (health and land to take two) that have witnessed violent protest and where arguably party-state control was tested, if not found wanting. ${ }^{27}$ She notes the choice between resilient and rigid stability available to the Chinese, contending that China has, at this time, opted for the latter. ${ }^{28}$ Arguably the very violence of Chinese protest on a range of policies provokes more repressive attitudes to political protest, which Biddulph chronicles. ${ }^{29}$

A more modest thesis (because it excludes individual action from its analysis) argues that Chinese constitutional debate is a deliberative strategy of the Chinese Communist Party: where the shape of the deliberation is framed and managed by the party-state. ${ }^{30}$ Baogang He and Mark Warren argue that authoritarian states legitimate participatory and consultative practice to produce "authoritarian deliberation and its associated

\footnotetext{
22. On the significance of political will to transplants see Daniel BERKOWITZ, Katharina PISTOR, and Jean-Francois RICHARD, "Economic Development, Legality, and the Transplant Effect" (2003) 47 European Economic Review I65. See also Otto KAHN-FREUND, "On Uses and Misuses of Comparative Law" (I974) 37 Modern Law Review I.

23. 2013 Constitution of the Socialist Republic of Vietnam (adopted 28 November 20I3). See also Statute of the Communist Party of Vietnam, 20 I I and Resolution Number 49 NQ/TW (2 June 2005), Central Committee Communist Party of Vietnam, 'On the Judicial Reform Strategy' ('Resolution 49').

24. Keith HAND, "Resolving Constitutional Disputes in Contemporary China" (2OI2) 7(I) University of Pennsylvania East Asia Law Review 5 I.

25. Ibid at $5 \mathrm{I}$.

26. Ibid at 57 .

27. Sarah BIDDULPH, The Stability Imperative: Human Rights and Law in China (Vancouver, Toronto: University of British Columbia Press, 20I 5 ) at 82-I70.

28. Ibid at 8-9. In framing this choice Biddulph draws on the work of Yu Jianrong.

29. Ibid at I9I-99.

30. Baogang HE and Mark E WARREN, “Authoritarian Deliberation: The Deliberative Turn in Chinese Political Development” (20II) 9(2) Perspectives in Politics 269.
} 
ideal-type regime as deliberative authoritarianism". ${ }^{3 \mathrm{I}}$ They argue that instigating deliberation in this way enables the Chinese leadership to "manufacture consent". ${ }^{32}$ And in large part He and Warren argue that the Chinese leadership retains a monopoly on the ultimate shape and form of debate, noting that deliberative authoritarianism can leave open the possibility of transforming authoritarianism. ${ }^{33}$

It is extremely difficult to determine the causes and the consequences of legal change in the "ping pong" model of dialogue that deliberative authoritarianism affords. ${ }^{34}$ That said, He and Warren's analysis of deliberative authoritarianism resonates as a relevant analytical frame for the Vietnamese party-state's use of allowing debate while "controlling dissent and maintaining order", ${ }^{35}$ arguably done in the name of maintaining peace and security. ${ }^{36}$

In contrast, Dowdle argues that whether or not the constitutional dialogue in China is managed, new understandings of constitutionalism can manifest where there is dialogue "between the popular and formal component of constitutionalism" and that dialogue is "not unilateral". ${ }^{37}$ I do not need to engage Dowdle's wider thesis that popular constitutionalism exists in China, ${ }^{38}$ to accept his argument that the "conceptual mappings of its [China's] constitutional trajectories" may be forever changed by the dialogue provoked through Charter $\circ 8^{39}$ and through growing constitutionalist discourse also. ${ }^{4}$ Dowdle's thesis shares much with $\mathrm{He}$ and Warren and Hand's work - all three note the dialogical nature of party-state relations; but Dowdle argues that reform can flow from the dialogue incrementally and not entirely reflecting the party-state's design, and the focus should be on the National Assembly as a key player in these debates, rather than on courts. ${ }^{4 \mathrm{I}}$ Dowdle's thesis was written before the crackdown on dissent and the current

\section{I. Ibid at 269 .}

32. Ibid at $28 \mathrm{I}$.

33. Ibid at $27 \mathrm{I}$.

34. In earlier work Bui Ngoc Son and I have chronicled the methodological issues this analysis raises (see Bui and Nicholson, supra note I, also admitted by He and Warren, supra note 30 at 279.

35. He and Warren, supra note 30 at $28 \mathrm{I}$.

36. Party Resolutions routinely note that the CPV has to maintain the peace and security of the nation, and is its absolute leader: Resolution No. 8 of the CPV dated 2 February 2002 ; Resolution No $48-\mathrm{NQ} / \mathrm{TW}$, CPV Politburo Resolution on Strategy for Building and Reforming Legal System of Vietnam up to 20I0, an Orientation to 2020, 24 May 2005 (Resolution 48); Resolution 49; Resolution No 900/UBTVQHi I For the Action Plan to Implement Resolution No 48-NQ/TW dated 24 May 2005 on the Strategy for Development and Improvement of Vietnam's Legal System to the Year 2010 and Direction for the Period 2020, I 2 March 2007; Conclusion 92 on Continuing to implement Resolution no. 49-NQ/TW, dated 2 June 2005, of the Politburo term IX on the Judicial Reform Strategy to 2020, I4 February 20I4 (Resolution 92). See also the Vietnam National Party Congress Reports.

37. Michael W DOWDLE, "Popular Constitutionalism and the Constitutional Meaning of Charter $\circ 8$ " in Jean-Phillipe BÉJA, FU Hualing, and Eva PILS, ed, Liu Xiaobo, Charter o8, and the Challenges of Political Reform in China (Hong Kong: Hong Kong University Press, 2012) 205 at 210 [Dowdle, "Charter ०8"]. On reform dialogue and the role of the National Assembly, see also Michael W DOWDLE, "Of Parliaments, Pragmatism, and the Dynamics of Constitutional Development: The Curious Case of China" (2002) 35(I) NYU Journal of International Law and Politics I [Dowdle, "Curious Case"].

38. Dowdle, "Charter o8", supra note 37.

39. Dowdle, "Charter o8", ibid at 228.

40. Dowdle, "Curious Case", supra note 37 at 50-105.

4I. Ibid at 9-IO, I8, 29-30, I83-94. 
Chinese leadership's escalation of control. Whether recent changes challenge the thesis, suspend it, or leave it unchanged, time will tell.

Significantly, the dynamics of constitutional debate do not necessarily produce liberal reform, no matter how much notions of liberalism inform some of the reform actors. Dowdle notes that scholars steeped in the liberal tradition are constrained in how they think about constitutional transformation by "structuralliberal ideology" which has a finite list of possibilities for constitutional reform. ${ }^{42}$ Dowdle asks scholars not to see if there has been the adoption of liberal constitutionalism, but to analyze constitutional dialogue to see what it reveals. ${ }^{43}$ And that is the challenge taken up by these papers. That said, the assembled papers largely assume a binary contest between liberally-inspired reforms and socialist authoritarianism. While the constitutional tussles may be largely cast as liberal versus authoritarian, the upshot of the debates may well not reflect the debates. It would be a mistake to understand the narratives set out here as confirming reform as inevitably reflecting liberal democratic principles, ${ }^{44}$ even if many actors argue for these models.

In short, the papers suggest that Vietnamese constitutional dialogue is allowed to be relatively vibrant and wide-ranging, arguably more so than its Chinese counterpart. The papers demonstrate that across the range of issues taken up, key questions were asked as a part of the consultations. Further, the papers do not set out the details of a regressive and conservative constitutional movement as has been fostered in Chinese scholarship. ${ }^{45}$ It has been noted that there are conservative elements contributing to the debates. ${ }^{46}$ So how do those who debate legal power structures compare with Vietnamese activists and how are they treated?

\section{VIETNAMESE POLITICAL ACTIVISM}

Kerkvliet offers the first analytical study of disagreement between the CPV and its critics. ${ }^{47}$ Kerkvliet studies dissidents-and not those involved in constructive constitutional dialogue. The relevance to this brief paper lies in how the state responds to dissidents, who are in turn disaggregated by Kerkvliet into a range of actors. ${ }^{48}$ Kerkvliet concludes that the dissidents and the party-state share a common set

42. Ibid at $199-200$.

43. Ibid.

44. Bui, Confucian Constitutionalism, supra note I6.

45. Samuli SEPPÄNEN, "Ideological Renewal and Nostalgia in China's 'Avant-Garde' Legal Scholarship" (2014) I3(I) Washington University Global Studies Law Review 83. See also Samuli SEPPÄNEN, Ideological Conflict and the Rule of Law in Contemporary China: Useful Paradoxes [forthcoming in 20I6].

46. See for example, Vo, supra note I I at I7-I9 and groups as coercive/enforcement units (police, army etc), conservative politicians and red capitalists.

47. Benedict J Tria KERKVLIET, "Government Repression and Toleration of Dissidents in Contemporary Vietnam" in Jonathan D LONDON, ed, Politics in Contemporary Vietnam: Party, State, and Authority Relations (London: Palgrave Macmillan, 2014) I00 at 102.

48. See Vo, supra note I r. See also BUI Hai Thiem, “Constitutionalizing Single Party Leadership in Vietnam: Dilemmas of Reform", this volume. 
of "ideals" including "development, democracy, and nationalism". ${ }^{49}$ This commonality of aspirations for Vietnamese reform is arguably also generally present in the constitutional actors depicted in the following papers. The dialogues chronicled emanate from a deeply-held nationalism that wishes to witness the escalation of development (whether for land and human rights or economic growth, for example) and greater democratization (whether liberal-inspired or a unique Vietnamese Partystate variant). That said, those involved in constitutional debate position their arguments largely assuming the survival of the Communist Party of Vietnam. Unlike some of the political activists, the reform arguments chronicled in the following papers are not blunt calls for multiparty democracy. They suggest nuanced and detailed arguments about change either without detailed reference to the overall party-state architecture or conceding (possibly strategically) that renovating the CPV could deliver reforms enabling stable, if more open government.

Kerkvliet also notes that there has been a long-standing openness to dialogue at least by some leaders. ${ }^{50}$ And this general openness set out by Kerkvliet has been confirmed in the constitutional realm also. ${ }^{5 \mathrm{I}}$ This openness does not preclude the party-state from being repressive. ${ }^{52}$ Kerkvliet sets out the divergent treatment of the 62 dissidents studied, noting there is more sympathy for those highly critical of the State who are aged, with a history of service to the Party, and who are not determined to overthrow the party. ${ }^{53}$ It is noted that this is different from the near-uniform treatment of dissidents in China. ${ }^{54}$ This characterization of the State's quasi-permissive treatment of both public figures and people with good party-state credentials (war heroes, intellectuals) holds true for those involved in constitutional debate also. While Nguyen Dinh Loc, the former Minister of Justice who handed over Petition 72, was reportedly harassed by authorities, his high regard precluded explicit sanctioning of his conduct. ${ }^{55}$

I suggest here that Vietnamese constitutional dialogue and its aftermath have differed from the Chinese experience. First, and as set out in the ensuing papers, Vietnam has officially allowed gradually escalating constitutional debate culminating in Petition 72 and the work of other groups agitating, albeit constructively, for reform, ${ }^{56}$ and this permissiveness has a long history. ${ }^{57}$ The treatment of the 72 petitioners, while not without application of party-state pressure, diverges from the harsh penalties for those involved in Charter o8 in China. ${ }^{58}$

49. Kerkvliet, supra note 47 at II 3 .

50. Ibid at II4.

5I. Note the long-standing tradition of scholarly argument for reform and the ongoing manifestation of reform debates in the more recent past. See Bui and Nicholson, supra note I at I6-26.

52. Kerkvliet, supra note 47 at I I4-I6. See also Carlyle A THAYER, "The Apparatus of Authoritarian Rule in Vietnam" in Jonathan D LONDON, ed, Politics in Contemporary Vietnam (London: Palgrave Macmillan, 20I4) I 35 .

53. Kerkvliet, supra note 47 at I 29.

54. Ibid at 128.

55. Bui and Nicholson, supra note I at 42-44.

56. Vo, supra note II at 24-33.

57. Bui and Nicholson, supra note I at I6-26.

58. See e.g. Pitman B POTTER and Sophia WOODMAN, "Boundaries of Tolerance: Charter $\circ 8$ and Debates over Political Reform” in Jean-Phillipe BÉJA, FU Hualing, and Eva PILS, ed, Liu Xiaobo, Charter o8, 
Secondly, China and Vietnam might both aspire to deliberative authoritarianism, but in the sphere of constitutional debate Vietnam is either deliberately more permissive or less able to control the discussions. At least some of the ensuing papers, and also the work by Bui Ngoc Son and Nicholson, suggest that the Vietnamese party-state, at least partially, lost control of the constitutional debate in 20I 2-20I $3 .{ }^{59}$ And many constitutional reformers responded favourably to the invitation to debate any issue. The space for debate, however, is radically reduced once the decisions about the constitution were made. Vietnamese democratic centralism demands that once a policy/political position has been settled, all relevant actors accept the script/order. ${ }^{60}$

Thirdly, the treatment of constitutional dialogue, as portrayed in these papers, suggests at least some parallels with the characterization of party-state treatment of Vietnamese dissidents offered by Kerkvliet. Petition 72 was launched by a former Minister of Justice, Nguyễn Đình Lộc, and backed by a group of 72 intellectuals and informed citizens, many of whom had closely worked with VCP over many years to support the state and its administration. This was not a group of "trouble-makers" but deeply concerned citizens seeking to reinvigorate and bolster reform to enable a government commanding the people's respect. Reformers specifically identified the possibility of the ongoing leadership of the VCP, particularly if it demonstrated its capacity to reform. ${ }^{6 \mathrm{I}}$ And this constructive spirit is echoed in the papers published here also.

It is therefore possible to suggest that at least some reformers can argue for more fundamental reform in Vietnam than in China with fewer repressive consequences. This is a reality for the actors outlined in the following papers, if incremental reform is accepted by all actors. Further, if reform manifests through deliberate ambiguity less pressure is placed on all actors and some changes might come to pass over time. If we accept that reform debates spawn new constitutional possibilities, the reform dynamics in Vietnam may have more impact and may realize change in advance of their northern neighbor, albeit that the reforms may not resemble Western, liberal constitutionalism. Vietnam has embraced the use of constitutional ambiguity to bridge reformist and non-reformist differences. While this is not unique to Vietnam, it affords more space for incremental change, and arguably more space than available previously.

and the Challenges of Political Reform in China (Hong Kong: Hong Kong University Press, 201 2) 97. See also Jean-Phillipe BÉJA, “Is Jail the Only Place Where One Can "Live in Truth?” in Jean-Phillipe BÉJA, FU Hualing, and Eva PILS, ed, Liu Xiaobo, Charter o8, and the Challenges of Political Reform in China (Hong Kong: Hong Kong University Press, 201 2) I 5.

59. Bui and Nicholson, supra note I at 42-44.

6o. See Statute of the Communist Party of Vietnam (20I I) Art 9. See also its Preamble.

6I. Bui and Nicholson, supra note I at 57. 